\title{
İngiliz Yazılı Basınına Göre Bab-1 Ali Baskını ve Uluslararası Sonuçları
}

\author{
DOI: 10.26466/opus.512811 \\ * \\ Özgür Çınarlı* \\ * Dr. Öğr. Üyesi, Aksaray Üniversitesi, İktisadi, İdari Bilimler Fakültesi, Uluslararası İlişkiler \\ Bölümü, Aksaray / Türkiye \\ E-Posta: ozgurcinarli@hotmail.com \\ ORCID: 0000-0002-9436-9284 \\ ** Dr. Öğr. Üyesi, İstinye Üniversitesi İktisadi ve İdari Bilimler Fakültesi, Siyaset Bilimi ve Kamu \\ Yönetimi Bölümü, İstanbul / Türkiye \\ E-Posta: isafi@istinye.edu.tr \\ ORCID: $\underline{0000-0002-3672-5754}$
}

Öz

23 Ocak 1913 tarihinde, İttihat ve Terakki Partisi, iktidardaki Kamil Paşa Hükümetine karşı bir darbe yaparak iktidarı ele geçirmiştir. Bu darbe tarihe Bab-ı Ali Baskını olarak geçmiştir. Darbenin nedeni 1. Balkan Savaşında Osmanlı Devletinin uğradığı yenilgi sonucunda, Büyük Güçlerin Osmanlı Devletine Ege'deki adaların ve eski başkentlerden biri olan Edirne şehrinin teslim edilmesi yönündeki Notasına Kamil Paşa Hükümetinin olumlu yanıt vermek üzere oluşudur.Itttihat ve Terakki'nin amacı ise eldeki tüm olanaklar kullanarak bu bölgelerin elde tutulmasıdır. Ancak bu amacı gerçekleştirebilmesi mümkün olmamıştır. Enver Paşa öncülüğ̈̈nde gerçekleşen ve Türk siyasi hayatında önemli bir kırılma noktası olan Bab-ı Ali Baskını önemli bir yer teşkil eder. Demokrasi tarihimizdeki ilk darbelerden biri olarak niteleyebileceğimiz bu olayla birlikte İttihat ve Terakki'nin tek başına yönetimi ele geçirmesi sonucu ortaya çıkar. Bu çalışmada Bab-ı Ali Baskını, İngiliz yazılı basın kaynaklarına dayanarak, süreç ve sonuçlarıla incelenirken, Ege'deki adaların ve Edirne'nin elde tutulması konusunda başarılı olunamaması, iç ve dış nedenleriyle ele alınmaktadır.

Anahtar Kelimeler: Bab-ı Ali Baskını, Balkan Savaşı, İttihat ve Terakki, Jöntürkler, darbe 


\title{
The Raid of the Porte and Its International Repercussions According to the British Press
}

\begin{abstract}
In $23^{\text {th }}$ January 1913, Union and Progress Party organized a coup against the leading Kamil Pasha Cabinet and aquired power. This coup is named as "the raid of the Porte". The main reason of the coup was Kamil Pasha Cabinet's acceptance of the memorandum of the Great Prowers, which was given after the defeat of the Ottoman forces in the first Balkan War and included the surrender of one of the oldest capitals of Edirne and the Islands in the Eagean sea. The aim of the Union and Progress Party was the protection of these reagions, by monopolizing every possibility at hand. The raid of the Porte, an important breakpoint in Turkish politics, is an important area under the leadership of Enver Paşa. In the history of democracy in Turkey, one of the first coups can be seen as a consequence of the monopolization of political power by the Union Committee and Progress. However, they could not be successful in reaching this aim. This work observes the process and the repercussions of the coup by using the British print media, and puts forward the failure of its aim, with its internal and external reasons.
\end{abstract}

Keywords: The raid of the Porte, Balkan War, Union and Progress, Young Turks, coup 


\section{Giriş}

1. Balkan Savaşı'nda Osmanlı Devleti'nin ağır bir askeri yenilgi alıp Edirne'nin Bulgar Ordusu tarafından kuşatıldığı ve Bulgar Ordusunun Çatalca'ya kadar ilerlemiş olduğu sırada, İngiltere, Fransa, Rusya, Almanya, İtalya ve Avusturya-Macaristan İmparatorluğundan oluşan "Büyük Güçler"in inisiyatifiyle Osmanlı Devleti ile Balkan İttifakı arasında ateşkes yapılarak, Londra'da barış görüşmeleri başlatılmıştır. Ancak Büyük Güçlerin Londra'daki Büyükelçilerinin düzenlemiş olduğu Büyükelçiler Konferansında Osmanlı Devleti'ne Edirne'nin Balkan İttifakına teslimi ve Ege'deki adaların da Büyük Güçlere devredilmesi gibi oldukça ağır hükümler içeren bir Nota verilmiştir. Devletin askeri ve mali durumu ile mevcut uluslararası koşulları değerlendiren Kamil Paşa Kabinesi, şartları kabul edip barış yapmaya karar verdiği sırada, İttihat ve Terakki Partisinin düzenlediği bir darbeyle devrilerek, Mahmut Şevket Paşa'nın Sadrazamlığında İttihat ve Terakki hükümeti kurulmuştur. Tarihte 23 Ocak 1913 Bab-1 Ali Baskını olarak geçen bu olayın, savaşın yeniden başlamasına kadar uzanan önemli uluslararası sonuçları olmuştur. Çalışmada Bab-ı Ali Baskını süreç ve sonuçları bakımından İngiliz yazılı basınına dayanarak incelenirken, temelde Edirne'yi ve Ege'deki adaları elde tutmayı amaçlayan bu hareketin, amacına ulaşamadığı nedenleriyle birlikte ortaya koyulmaktadır.

\section{Babiali Baskını ve İngiliz Basınına Yansımaları}

Baskın öncesinde Kamil Paşa Hükümetine yönelik ordu içindeki rahatsızlıklar 6 Ocak tarihli haberlerde yer almaktadır. Bu haberlere göre yaklaşık yüz elli kadar subay, Çatalca'dan İstanbul'a gelerek, Nazım Paşa'nın Harbiye Nazırlığından ve Genelkurmay Başkanlığından azledilerek, yerine İzzet Paşa'nın atanmasını talep etmişlerdir. Hemen ardından Nazım Paşa'nın Genelkurmay Personeliyle birlikte Çatalca'ya gitmesi ise "siyasete karışarak yeni bir kriz tehdidi oluşturan ordu ve subaylar" üzerindeki otoritesini güçlendirmeye çalışması olarak yorumlanmıştır (The Aberdeen Daily Journal, 1913, 6 Ocak; The Manchester Courier, 1913, 6 Ocak). Çünkü Kamil Paşa Hükümetinin bir an önce barış yapılmasını istediği, ancak ordudaki savaşı sürdürme yanlısı 
subaylardan çekindiği düşünülmektedir (The Manchester Courier, 1913, 7 Ocak). Hatta bir gazetede açıkça “Ne yazık ki İstanbul'da Jöntürklerin iktidar talepleri ve ordu üzerindeki etkileri, Kamil Paşa'nın Balkan İttifakının taleplerine boyun eğmesini zorlaştırıyor" ifadesi yer almıştır (The Manchester Courier, 1913, 13 Ocak).

Fakat aynı zamanda Nazım Paşa, Çatalca'da Bulgar Genelkurmay Başkanı General Savoff ile de bir görüşme yapmıştır. Hariciye Nazırı Noradunkyan Efendi'nin de bulunduğu bu görüşmenin içeriğinin ilk başta gizli tutulması, Edirne'nin teslim şartlarının ayrıntılarının görüşüldüğü yönünde tahminlere yol açmıştır (The Evening Telegraph and Post, 1913, 9 Ocak). Ancak bu görüşmede Osmanlı Heyeti, Edirne'ye gida ikmali yapılmasına izin verilmesini talep etmiş, fakat General Savoff, bu konunun ateşkes şartlarında çözümlenmiş olduğu gerekçesiyle bu talebi reddetmiştir (The Aberdeen Daily Journal, 1913, 10 Ocak; The Manchester Courier, 1913, 10 Ocak; The Western Times, 1913, 10 Ocak). Bu görüşmede General Savoff'a iletilen diğer bir teklif de, Bulgaristan'ın Edirne'den vazgeçtiği takdirde, Bulgaristan'a Osmanlı'nın elinde kalan Trakya'nın Ege kıyılarından toprak verilebileceğidir. General Savoff bu teklifi Kral Ferdinand'a ileteceğini söylese de, bu tekliften de bir netice çıkmamıştır (The Courier, 1913, 13 Ocak).

Esasen Kamil Paşa Hükümetinin bu diplomatik çabasının bir sonuca ulaşması mümkün görünmemektedir. Öncelikle, ateşkes hükümlerine göre Bulgaristan'ın Edirne civarındaki ve Çatalca hattındaki birliklerine lojistik ikmali yaparken, Osmanlı Devletinin Edirne'ye lojistik ikmali yapamaması, Edirne'yi kuşatmış durumda olan Bulgaristan'ın, barış görüşmeleri sırasında elini güçlendiren en önemli avantajdı. Herhangi bir ciddi karşılık öne sürmeden Bulgaristan'ın elindeki bu avantajdan vazgeçebileceğini düşünebilmek gerçekçi değildir. Diğer yandan Bulgar ordusu halihazırda Ege Denizine ulaşmış durumdaydı. Bu bölgenin antlaşmadan sonra Bulgaristan'ın elinde kalıp kalmayacağı, Osmanlı Devletinden ziyade Büyük Güçlerin ve diğer Balkan Devletlerinin politikalarına daha çok bağlıydı.

Bu yüzden Kamil Paşa Hükümetinin bu diplomatik çabası, herhangi bir yarar sağlamadığı gibi, zafiyetin açıkça ilan edilmesi gibi çok önemli bir olumsuzluk doğurmuştur. Nitekim bu görüşmeden sonra, Edirne'de 
durumun oldukça vahim olduğu, her gün pek çok Osmanlı subay ve askerinin şehirden firar ettiği, ekmek dişında bütün yiyecek maddelerinin tükendiği, kişi başı günlük ekmek istihkakının da yüz gramın altına düştüğü, dolayısıyla şehrin herhangi bir çatışma olmaksızın en geç on gün içinde teslim olacağı yönünde haberler çıkmaya başlamıştır (The Aberdeen Daily Journal, 1913, 10 Ocak; The Manchester Courier, 1913, 10 Ocak; The Western Times, 1913, 10 Ocak). Edirne'deki Osmanlı Ordusunun lojistik sıkıntısının bu denli abartılarak haber yapılmasının, ${ }^{1}$ Balkan İttifakına moral destek sağladığı aşikardır.

Kamil Paşa Hükümeti bu diplomatik çabadan olumlu bir sonuç alamayacağını, hatta yukarıda bahsedildiği gibi olumsuz yorumlara neden olabileceğini öngörememiş midir veya hiç ümidi olmamasına rağmen şansını denemek mi istemiştir veya Edirne'nin teslimini kabul etmeye karar verip de sadece iç politikada Edirne'yi elde tutmak için elinden geleni yaptı̆̆ izlenimini mi vermeyi amaçlamıştır? Mevcut basın kaynakları ışığında bu sorulara yanıt bulmak mümkün görünmemektedir. Ancak 23 Ocak tarihli gazetelerde Osmanlı Devletinin Edirne'yi teslim edip barış antlaşmasını imzalamaya karar verdiği ifade ediliyor. Kamil Paşa Hükümetinin bu kararında ise en önemli etmenin devletin içinde bulunduğu mali kriz olduğu öne sürülmektedir. Nazım Paşa'nın “Mali durum elverseydi savaşı sürdürürdüm. Fakat Maliye Nazırının mali durumun savaşı sürdürmeye elverişli olmadığı görüşünü alınca barışı kabul ettim" ifadesine yer verilmiştir (The Evening News, 1913, 23 Ocak). Diğer bir faktörün ise Rusya'nun tehditi olduğu öne sürülmektedir (The Manchester Courier, 1913, 23 Ocak). Kararın alınıs süreci hakkında daha ayrıntılı bir şekilde bilgi veren bir basın organına göre ise "Büyük Meclis"in² karşısında Maliye Nazırının mali durumun savaşı sürdürmeye uygun olmadığını, Hariciye Nazırı Noradunkyan Efendi'nin de uluslararası koşullarda Edirne'nin ve Ege'deki adaların elde tutulmasının

\footnotetext{
${ }^{1}$ Elbette Edirne'deki Osmanlı kuvvetlerinin ciddi şekilde gıda ve ilaç sıkıntısı olduğu doğrudur. Ancak Edirne'deki Osmanlı kuvvetlerinin çatışmaların yeniden başlamasından sonra bile Bulgar Ordusuna karşı başarıyla direnmesi ve ancak ağır silah bakımından oldukça güçlü Sırp Ordusunun, Bulgarlara yardıma gelmesiyle Edirne'nin düştüğü dikkate alındığında, "gıda sıkıntısı dolayısılla en geç on gün içinde kendiliğinden teslim olacağı" gibi bir ifadenin gerçeği yansıtmadığı görülmektedir.

2 Burada "Büyük Meclis" olarak ifade edilen, üyeleri seçimle belirlenen Meclis-i Mebusan değil, üst düzey bürokratlardan oluşan ve danışma kurulu niteliğinde olan Şura-yı Umumi’dir. Bu tarihte Meclis-i Mebusan feshedilmiş durumdadır.
} 
mümkün olmadığını ifade ettiği, Nazım Paşa'nın "Savaşı sürdürmek isteyen varsa ayağa kalksın" sözü karşısında kimsenin yerinden kalkmayarak, neredeyse oybirliğiyle antlaşma yapılmasının kabul edildiği belirtilmektedir (Yorkshire Telegraph and Star, 1913, 23 Ocak).

Darbeyle ilgili ilk haberler ise 24 Ocak tarihli gazetelerde yer almaya başlamıştır. Kamil Paşa Hükümetinin teslimiyetçi tutumu ve Edirne'yi teslim etmeye karar vermesinin Jöntürk "devrimine" 3 yol açttğ̆1, Kamil Paşa Hükümetinin düşüp, Mahmut Şevket Paşanın Sadrazamlığında Jöntürk Hükümeti kurulduğu, Jöntürklerin Edirne'yi elde tutma konusunda kararlı olduğu ve Balkan İttifakının Edirne konusunda 1srar etmeye devam etmesi durumunda savaşın yeniden başlamasının kaçınılmaz olduğu ifade edilmektedir (Sunderland Daily Echo, 1913, 24 Ocak; The Derby Daily Telegraph, 1913, 24 Ocak; The Evening News, 1913, 24 Ocak; The Nottingham Evening Post, 1913, 24 Ocak; The Yokshire Evening Post, 1913, 24 Ocak). Baskınla ilgili bir yorumda ise bir ay önce Jöntürk liderlerinin darbe yapacakları gerekçesiyle tutuklandıkları, bu yüzden de baskının aynı zamanda intikam amaçlı olduğu öne sürülmektedir (The Yokshire Evening Post, 1913, 24 Ocak).

İlk haberler arasında, baskın sırasında Nazım Paşa'nın öldürüldüğü haberine de yer verilmektedir. Ayrıntıya girilmeyen bu haberlerde, Jöntürk liderlerinin kan dökülmemesi yönündeki kesin talimatlarına rağmen, hükümet karşıtı gösteriler sırasında, Nazım Paşa'nın yaverinin Enver Bey ve yanındakilere ateş açması üzerine, açılan karşı ateş sonucu Nazım Paşa'nın vurularak öldüğü (Sunderland Daily Echo, 1913, 24 Ocak; The Derby Daily Telegraph, 1913, 24 Ocak; The Evening News, 1913, 24 Ocak; The Nottingham Evening Post, 1913, 24 Ocak; The Yokshire Evening Post, 1913, 24 Ocak) bilgisi yer almaktadır. ${ }^{4}$

\footnotetext{
${ }^{3}$ Ingiliz basınında Bab-ı Ali baskınıla ilgili haber başlık ve içeriklerinde "darbe" yerine "devrim" ifadesi kullanılması dikkat çekicidir. Ancak ileri tarihli az sayıda basın organında "devrim" ifadesi sorgulanmakta veya "darbe" ifadesi kullanılmaktadır.

${ }^{4}$ Nazım Paşa'nın öldürülmesiyle ilgili bu ilk haberlerin ayrıntılı olmayışlarının nedeni ittihat ve Terakki Hükümetinin, Nazım Paşa'nın ölümüyle ilgili haberlere sansür yasağı getirmiş olmasıdır. Dönemin koşullarında bilgi iletiminin temel aracı telgraf olduğundan dolayı sansürün uygulanması oldukça kolaydır. Pek çok gazete Reuter kanalıyla ve telgraf aracılığılla dış haberleri edinmektedir. Az sayıda basın kuruluşunun yurtdışında muhabirleri bulunmaktadır ve bu muhabirler de telgraf araclığıyla haber iletmektedir. Bu muhabirlerin sansürü aşabilmelerinin yolu da ancak Istanbul dışına çıkarak, başka bir yerden telgraf çekmeleridir. Nitekim istanbul'dan ayrılarak, başka merkezlerden telgraf çeken bazı muhabirler kanalıyla, ilerleyen günlerde konuyla ilgili daha ayrıntılı bilgiler verilmeye başlanmıştır.
} 
Bir gazetede ise Talat Bey'in Reuter muhabiriyle görüşmesi sırasında yaptığı açıklamalar ve yeni kabinenin yapmış olduğu duyurunun ayrıntılarına yer verilmiştir. Görüşme sırasında Talat Bey "Kabinenin istifasına neden olan ve oldukça hazırlıksız olan bu hareket, kabinenin Edirne konusundaki tavrına karşı gösterilen yaygın tepkinin sonucudur. Edirne teslim edilmişti ve imparatorluğun her yanında buna karşı ciddi bir rahatsızlık meydana geldi. Hiç bir şekilde taviz vermemiz söz konusu değildir. Para konusunda tüm millet fedakarlık gösterecektir. Hareketimiz milli onurumuzu korumak veya bu uğurda yok olmak anlamına gelmektedir. Savaşın devamını istemiyoruz, ancak Edirne'yi de elimizde tutmaya kararliyı" (The Yorkshire Telegraph and Star, 1913, 24 Ocak) şeklinde açıklamada bulunmuştur.

Yeni kurulan İttihat ve Terakki Hükümeti de ilan ettiği duyuruda eski kabineyi "hainler kabinesi" olarak nitelemekte, Said Paşa ve Ahmet Muhtar Paşa hükümetlerinin Arnavutluk üzerindeki devlet otoritesini sarstığını; bu zafiyetin Balkan ülkelerinin iştahını kabarttığını; Muhtar Paşa Kabinesinin Anayasaya son darbeyi indirdiğini ve bu yüzden Osmanlı aleyhinde bir Balkan Koalisyonu oluştuğunu; bu koalisyonun mevcudiyetinin bilinmesine rağmen kabinenin yüz yirmi bin askeri terhis ettiğini; Rusya'nın koalisyona savaşı bahara ertelemesini önermesine karşı Bulgar Kralı Ferdinand'ın "Baharda iktidarda böyle zayıf bir hükümet bulamayız" dediğini; Genelkurmay'ın Balkan koalisyonuna karşı bir savaş planı hazırlamasına rağmen, Muhtar Paşa ve Kamil Paşa hükümetlerinin bu planı tatbik etmek yerine en yeteneksiz subayları komutanlıklara atadığını; düşmana karşı savaşmak yerine dürüst insanlara zulmettiğini; kabinenin ordunun savaşma azmini ve halkın vatanseverlik duygusunu yok ettiğini; Kamil Paşa Hükümetinin savaşla ilgilenmek yerine, Abdülhamid Rejimini yeniden inşa etmeye uğraştığını; Balkan Koalisyonunun çıkarına olan bir ateşkes anlaşması imzalayarak, Londra Konferansında da tüm Rumeli'yi teslim etmek üzere olduğunu; bu zafiyeti gören Balkan Koalisyonunun Edirne'yi ve Ege'deki adaları talep ettiğini; Balkan Koalisyonunun temsilcilerinin Büyük Güçleri kendi yanlarına çekmeyi başardığını ve Kamil Paşa Kabinesinin de bu tavizlere onay verdiğini; Şura-i Umumi'de kabinenin ülkeye ihanet edip Osmanlı ruhunu yok ettiğini; Anayasayla yönetilen ülkelerde bu tür meclislerin olamayacağını; Kamil Paşa Hükümetinin Edirne ve Ege'deki adaları 
teslim ederken bu ihanetini gizlemek için Şura-yi Umumi'yi kullandığını; bu tavizleri verirken milletin en kutsal haklarına saldırdığını; Osmanlı Devletininin bu "işbirlikçiler kabinesi"ne tahammül edemeyeceğini; ülkenin varlığı tehlikedeyken milletin devrim yapma hakkını kullandığını; Padişahın ülkeyi korumak için milletin tüm gücünü kullanacak olan yeni hükümeti onayladığını; Osmanlı Milletinin Rumeli'deki haklarından taviz veremeyeceğini ve bu hakları korumak için tüm gücünü kullanacağını; Osmanlı Milletinin onuruyla yaşamak istediğini tüm dünyaya göstereceğini belirtmektedir (The Yorkshire Telegraph and Star, 1913, 24 Ocak).

Aynı gazetede Osmanlı Ordusunun durumuyla ilgili bilgiler de yer almaktadır. Verilen bilgilere göre Çatalca'daki orduya rezervler, Anadolu'dan getirilen birlikler, Nizam birlikleri ve bunların modern silahlarıyla takviye yapılmış, askerlerin sağlık durumu düzeltilmiştir. Ancak beslenme henüz yeterli seviyede değildir. Sayısal olarak ise Osmanlı'nın Rumeli Ordusu 130 ila 150 bin arası askerden oluşmakta, 450 sahra, 50 hafif, 35 ağır topu bulunmaktadır. Ayrıca İzmit'te 50.000 asker, Gelibolu'da Fethi Bey komutasında, Çanakkale'yi savunacak 45.000 asker bulunmaktadır (The Yorkshire Telegraph and Star, 1913, 24 Ocak).

25 Ocak tarihli gazetelerde Bab-1 Ali baskınıyla ilgili haberlere, önceki günden daha fazla yer ayrılmış olduğu görülmektedir. Bunun nedeni olarak ilk başta dönemin haber iletim olanaklarının kısıtlı oluşu akla gelse de, esasen İstanbul'daki bu siyasi gelişmenin uluslararası etkilerinin kamuoyunda uyandırdığı ilgi olduğu anlaşılmaktadır. Çünkü bu haberle ilgili başlık ve içeriklerde "yeni hükümetin Edirne'yi elde tutma konusunda kararlı olduğu, barış olasılığının azaldığı, savaşın yeniden başlaması olasılığının da arttığı" yorumları ön planda yer almaktadır (Gloucaster Journal, 1913, 25 Ocak; Sunderland Daily Echo; The Aberdeen Daily Journal, 1913, 25 Ocak; The Courier, 1913, 25 Ocak; The Devon and Exeter Gazette, 1913, 25 Ocak; The Falkirk Herald, 1913, 25 Ocak; The Manchester Courier, 1913, 25 Ocak; The Western Times, 1913, 25 Ocak; The Yorkshire Post, 1913, 25 Ocak; Western Daily Press, 1913, 25 Ocak). Önceki hükümetle barış konusunda anlaşıldığı, (The Aberdeen Daily Journal, 1913, 25 Ocak; The Falkirk Herald, 1913, 25 Ocak) ancak Büyük Güçlerin Nota'sına verecek yanıtı tartışmak üzere toplanan yeni kabinenin kararının Nota'nın reddedilmesi yönünde olacağına kesin gözüyle 
bakıldığ 1 ifade edilmektedir (The Devon and Exeter Gazette, 1913, 25 Ocak; The Manchester Courier, 1913, 25 Ocak; The Western Times, 1913, 25 Ocak; The Yorkshire Post, 1913, 25 Ocak; Yorkshire Telegraph and Star, 1913, 25 Ocak). Hatta bazı tahminlere göre yeni kabine, eski hükümetin devrilmesine neden olan gösterileri, milli kararlılığın bir göstergesi olarak öne sürecektir (The Manchester Courier, 1913, 25 Ocak; The Western Times, 1913, 25 Ocak; Yorkshire Telegraph and Star, 1913, 25 Ocak).

Aynı tarihli gazetelerde, Londra'daki Osmanlı misyonuyla ilgili çelişkili haber ve yorumlarla karşılaşılmaktadır. Bazı haberlere göre yeni hükümet Osmanlı delegelerini geri çağırmıştır. Bu haberlerde Osmanlı delegelerinin yanı sıra, Viyana Büyükelçisi Hilmi Paşa ile St. Petersburg Büyükelçisi Türkan Paşa'nın da geri çağırıldığı haberleri beraber yer almaktadır (The Courier, 1913, 25 Ocak; The Western Times, 1913, 25 Ocak). Bazı gazetelerde ise sadece yeni durumla beraber, Osmanlı delegelerinin geri çağrılacaklarından emin oldukları (Gloucaster Journal, 1913, 25 Ocak) ve Osmanlı misyonunun bir hükmünün kalmadığı gibi haber ve yorumlar yer almaktadır (The Aberdeen Daily Journal, 1913, 25 Ocak; The Devon and Exeter Gazette, 1913, 25 Ocak). Ancak bir gazete Osmanlı delegelerinin geri dönecekleri yolundaki iddiaların asılsız olduğunu ve İstanbul'daki yeni hükümetin, delegelerine henüz bir talimat göndermediğini belirtmektedir (The Yorkshire Post, 1913, 25 Ocak). Osmanlı delegelerinin muhabirlerle yaptıkları görüşmelerde geri çağrılacakları yönündeki tahminlerini belirtmelerinin bazı muhabirler tarafından "geri çağrıldıkları yönünde bir talimat aldıkları fakat bu talimatı çeşitli nedenlerden dolayı basına açıklamamayı tercih ettikleri" şeklinde yorumlanmış olması kuvvetle muhtemeldir.

Balkan Koalisyonu delegeleriyle ilgili haberlerde ise bu tarz çelişkili bilgi ve yorumlara rastlanmamaktadır. Balkan Koalisyonu delegeleri, hükümetlerine telgraf çekerek yeni durumla ilgili hükümetlerinden talimat taleb etmişler, bazıları İngiliz Dışişleri Bakanlığını ziyaret etmiş ve saat 17:00 civarında Hyde Park Hotel'de, tüm Balkan Koalisyonu delegelerinin hazır bulunduğu bir toplantı yapmışlardır. Her ne kadar bu toplantıda, İstanbul'daki hükümet değişimi, Osmanlı Devletinin Büyük Güçlerin Notasına red yanıtı vereceğinin bir göstergesi olarak yorumlansa da, delegelerin bazılarına halen hükümetlerinden yeni durumla ilgili 
talimat gelmediği için bir gün daha beklemeye karar verdikleri belirtilmektedir (The Devon and Exeter Gazette, 1913, 25 Ocak; The Manchester Courier, 1913, 25 Ocak; The Western Times, 1913, 25 Ocak; The Yorkshire Post, 1913, 25 Ocak).

Esasen Balkan Koalisyonu delegelerinin, yeni durumla ilgili yeni talimatlar dışında beklemesini gerektiren başka konular da vardır. Bunların ilki, yeni durumla ilgili Büyük Güçlerin politikalarında bir değişim olup olmayacağı konusundaki belirsizliktir. Nitekim toplantıdan önce bazı delegelerin İngiliz Dışişleri Bakanlığını ziyaret etmeleri, başta İngiltere olmak üzere Büyük Güçlerin politikaları hakkında nabız yoklamasıdır. Ancak bu konu üzerindeki hassasiyet, İngiltere'nin politikasından ziyade, İstanbul'daki yeni hükümetin Almanya ve Avusturya-Macaristan ile ilişkileri ve bu ilişkilerin, bu ülkelerin politikalarında bir değişime neden olma olasılığı üzerinde yoğunlaşmaktadır.

Diğer konu ise, İstanbul'daki yeni hükümetin kalıcı olup olamayacağıdır. Her ne kadar İttihat ve Terakki Partisinin yaptığı darbe başarılı olmuşsa da, eski hükümetin de özellikle ordu içinde taraftarlarının olduğu bilindiğinden, bunların tepkisiyle, yeni kurulan İttihat ve Terakki Hükümetinin düşmesi ihtimali vardır. Böyle bir durumda, Ege'deki adaların ve Edirne'nin, yeni bir çatışmaya gerek kalmadan Osmanlı Devletinden alınabileceği öngörülmektedir. Fakat bir karşı devrim olmasa bile, ülke içindeki muhalefet dolayısıyla oluşacak istikrarsızlık, İttihat ve Terakki Hükümetinin dikkat ve enerjisini ülke içindeki meselelere sarf etmeye zorlayabilir ve Edirne'yi elde tutma konusundaki ssrarci tutumunda yumuşamaya neden olabilirdi. Bu bakımdan, konuyla ilgili haber ve yorumlarda, yeni hükümetin Almanya ve Avusturya-Macaristan ile ilişkileri, başta Almanya ve Avusturya-Macaristan olmak üzere Büyük Güçlerin Balkan meselesindeki tavırları ve İttihat ve Terakki Hükümetine karşı ülke içindeki muhalefet üzerinde özellikle durulduğu göze çarpmaktadır.

İttihat ve Terakki Partisinin muhaliflerinden Şerif Paşa'nın İstanbul'dan Paris'e geçerek, Temps dergisine vermiş olduğu beyanlar, İngiliz basınında da yer almıştır. Şerif Paşa, Bab-1 Ali baskınını Alman ve Avusturya-Macaristan'ın Osmanlı Devleti üzerindeki gizli etkisine bağlayarak, baskının Alman ve Avusturya-Macaristan komplosu olduğunu öne sürmüştür. Şerif Paşa'ya göre bu ülkelerin İstanbul'daki 
ajanları, “Osmanlı Devletinin çıkarlarının, Üçlü Antant ve de özellikle İngiltere ile çatıştığının" propagandasını yapmaktadırlar. Durumla ilgili oldukça karamsar olduğunu belirten Şerif Paşa, Türkiye'nin tüm Avrupa'yı karşısına aldığını ifade etmiştir. Osmanlı Devletinin mali durumunun elverişsizliğinden dolayı savaş olasılığını düşük gören Şerif Paşa, Osmanlı Devletinin Avrupa'daki topraklarını kaybettiği gibi, Anadolu'nun da işgale uğraması ihtimaline değinmiştir (The Aberdeen Daily Journal, 1913, 25 Ocak; The Devon and Exeter Gazette, 1913, 25 Ocak; The Yorkshire Post, 1913, 25 Ocak; Western Daily Press, 1913, 25 Ocak).

25 Ocak tarihinden itibaren, baskınla ve Nazım Paşa'nın öldürülmesiyle ilgili daha ayrıntılı bilgiler verilmeye başlanmıştır. Bu haberlerde, Enver Bey'in, hükümet karşıtı ve savaş yanlısı sloganlar atan kızgın bir kalabalığın önünde, atının üstünde Bab-1 Ali'ye girdiği, Kabine'nin toplantı halinde olduğu salona girerek, elinde hükümetin istifa belgesiyle çıktığı, kalabalığı yeniden "kışkırtarak," bir arabaya binip saraya yöneldiği bilgileri yer almaktadır. Bab-1 Ali önündeki kalabalık da gösteriye devam etmiş ve savaşa devam edilmesi gerektiği yönünde konuşmalar yapılmıştır (The Courier, 1913, 25 Ocak). Elinde Kamil Paşa Hükümetinin istifasıyla Saray'a geçen Enver Bey, Padişah ile yaklaşık bir saat süren bir görüşme yapmış, saat 20:00 civarında da Mahmut Şevket Paşa Saray'a gelerek, yeni hükümeti kurma görevini üstlenmiştir (The Courier, 1913, 25 Ocak).

Kamil Paşa'nın istifasının ayrıntılarıyla ilgili haberlerde, Enver Bey'in Kamil Paşa'dan ya savaşa devam edeceği yönünde yemin etmesini veya istifa etmesini istediği, yoksa daha fazla kan döküleceğini belirttiği, Kamil Paşa'nın ise soğukkanlı bir şekilde savaşa karşı olduğunu belirttiği ve istifa etmeyi tercih ettiği bilgileri yer almaktadır (The Aberdeen Daily Journal, 1913, 27 Ocak).

Baskın sırasında Nazım Paşa'nın öldürülmesiyle ilgili bazı haberler öncekileri teyit etse de, (Gloucaster Journal, 1913, 25 Ocak; The Aberdeen Daily Journal, 1913, 25 Ocak; The Daily Express, 1913, 25 Ocak; The Devon and Exeter Gazette, 1913, 25 Ocak; The Fife Free Press, 1913, 25 Ocak; The Manchester Courier, 1913, 25 Ocak; The Western Times, 1913, 25 Ocak; Western Daily Press, 1913, 25 Ocak; Yorkshire Telegraph and Star, 1913, 25 Ocak) bazıları da olayı farklı bir şekilde anlatmaktadır. Bu haberlere 
göre, İttihat ve Terakki taraftarları Bab-ı Ali'ye yaklaştığında, Nazım Paşa telefonla asker ve polisten yardım istemiş ancak yardımına kimse gelmemiştir. Göstericiler tarafından ateş açılmasına rağmen Bab-1 Ali muhafız birliği herhangi bir direniş göstermemiş, göstericiler Bab-1 Ali'ye girdiğinde ise Nazım Paşa vurularak ölmüştür (The Courier, 1913, 25 Ocak). Bab-1 Ali'deki muhafız birliğinin, göstericilere direniş göstermemesi bir gazetede, olaydan bir gün önce esas muhafızların, İttihat ve Terakki'ye bağlı muhafızlarla değiştirildiği bilgisine dayandırılmaktadır (The Aberdeen Daily Journal, 1913, 27 Ocak).

Bazı gazetelerde ise, öncekilerle çelişmeyen, ancak daha fazla ayrıntı içeren haberler yer almaktadır. Bunlara göre, göstericiler Bab-1 Ali'ye girdiği sırada, Sadrazam Yaveri Nafiz Bey göstericilere ateş etmiş ve açılan karşı ateş sonucu ölümcül şekilde yaralanmıştır. Harbiye Nazırı Yaveri ise göstericilerden Necip Bey'i vurmuş, ardından kendi de vurularak ölmüştür. Silah seslerini duyan Nazım Paşa, toplantı salonundan çıkıp olanları gördügüünde, göstericilere küfür ederken, kendisi de vurularak ölmüştür. Olaylar sırasında bir sivil polisin de vurularak öldügüunden bahsedilmektedir (The Manchester Courier, 1913, 25 Ocak).

Nazım Paşa'nın cenaze töreni ve başta yeni Sadrazam Mahmut Şevket Paşa olmak üzere İttihat ve Terakki Partisinin önde gelen liderlerinin törene katılımı da İngiliz basınında yer almıştır. Böylelikle İttihat ve Terakki liderlerinin, niyetlerinin aslında kan dökmek olmadığı, Nazım Paşa'nın ölümünün bir kaza olduğu yönünde bir mesaj verdiği yorumu yapılmıştır. Nitekim İttihat ve Terakki taraftarları arasında en çok nefret edilen kişi olan İçişleri eski Bakanı Reşit Bey'in diğer bütün eski bakanlarla beraber serbest bırakılması da bunun kanıtı olarak görülmüştür (The Courier, 1913, 25 Ocak; The Devon and Exeter Gazette, 1913, 25 Ocak; The Manchester Courier, 1913, 25 Ocak; The Yorkshire Post, 1913, 25 Ocak; Yorkshire Telegraph and Star, 1913, 25 Ocak).

İlerleyen günlerde de, Nazım Paşa'nın ölümüyle ilgili haberlerin İngiliz basınında yer almaya devam ettiği görülmektedir. Hatta bu haberlerin bazılarında Nazım Paşa'nın, kasten öldürüldüğü, ölümünden sonra yapılan otopside kurşun yaralarının yanı sıra bedeninde bıçak yaralarına da rastlanıldığı belirtilmektedir (The Aberdeen Daily Journal, 1913, 27 Ocak; The Courier, 1913, 27 Ocak; The Devon and Exeter Gazette, 1913, 28 Ocak; The Manchester Courier, 1913, 28 Ocak; Tounton Courier, 1913, 29 
Ocak). Nazım Paşa cinayetinin gündemde tutulmasının, iki önemli etkiye neden olacağı kolaylıkla öngörülebilir. İlki, uluslararası kamuoyu nezdinde yeni hükümete yönelik olası sempatiyi azaltması ve antipatiyi körüklemesidir. Nitekim bu durum bir gazetede açıkça şu şekilde ifade edilmiştir: "Türkiye'nin içinde bulunduğu zor duruma karşı Avrupa'da oluşan sempati, Nazım Paşa'nın öldürülmesi ve eski kabinenin terörize edilmesiyle ortadan kalktı" (The Mancester Courier, 1913, 28 Ocak), diğer etkisi ise yeni kurulan İttihat ve Terakki Hükümetine yönelik ülke içindeki muhalefeti kışkırtmasıdır.

Nitekim Osmanlı Devletindeki iç siyasi gelişmelerin, özellikle yeni kurulan İttihat ve Terakki Hükümetine karşı muhalif hareketler bağlamında dikkatle takip edilmeye devam edildiği görülmektedir. Hatta bu haberlerle ilgili bazı başlıklarda, "karşı-devrim olasılığı" gibi iddialı bir ifadenin yer alması dikkat çekicidir. Özellikle Halaskar Zabitan grubunun İttihat ve Terakki Hükümetinden duyduğu rahatsızlığın vurgulandığı görülmektedir.

Bu konudaki ilk ayrıntılı haber, Çatalca' dan üç tane askeri birliğin, İttihat ve Terakki Hükümetini devirmek üzere yola çıktığı haberi olmuştur. Bu haberin kaynağı olarak İstanbul'dan Burgaz'a gelen bir geminin haberi Burgaz'a getirdiği, bir gazetenin Sofya muhabirinin de Sofya-Burgaz arası telefon görüşmesiyle haberi öğrendiği gösterilmektedir (The Aberdeen Daily Journal, 1913, 27 Ocak; The Evening News, 1913, 30 Ocak; Yorkshire Telegraph and Star, 1913, 27 Ocak; Tounton Courier, 1913, 29 Ocak). Ancak böyle bir askeri hareketlilik vukuu bulmamıştır.

İlerleyen günlerde de benzer haberler İngiliz basınında yer almaya devam etmiştir. Çatalca'da Nazım Paşa taraftarları olan subayların durumu değerlendirmek üzere bir toplantı yaptığı, bu esnada Jöntürk grubu tarafından dağılmalarının istendiği, dağılmamaları üzerine çatışma çıktığı ve bu çatışmada kırk iki subayın öldüğü, yüz yetmiş subayın da yaralı olarak San Stefano Hastanesine sevk edildiği belirtilmiştir. Ayrıca Çerkes asıllı askerlerin Nazım Paşa'nın intikamını almak için yemin ettiği, Karadeniz girişindeki bir garnizonda da isyan çıtığı, Çanakkale Boğazındaki birliklerde de rahatsızlık olduğu, (The Courier, 1913, 31 Ocak; The Evening Telegraph and Post, 1913, 31 Ocak; The Manchester Courier, 1913, 30 Ocak; The Yorkshire Evening Post, 1913, 30 Ocak; Yorkshire Telegraph and Star, 1913, 30 Ocak) İstanbul'a gelen muhalif bir üst rütbeli 
subayın, İzzet Paşa'yı komutan olarak tanımadıklarını beyan edip Çatalca'ya gelmemesi konusunda tehdit etmesi, Çerkes asıllı süvarilerin, İttihat ve Terakki yanlısı Turgut Paşa'nın komutasındaki birliğe saldırıp bu birliği dağıttığı, Enver ve Fethi Beylerin siyasi bir konuşma yapacakları bir sırada muhalifler tarafından engellendikleri, bu sırada çıkan çatışmada pek çok subayın yaşamını yitirdiği (Dundee Evening Telegraph and Post, 1913, 3 Şubat) gibi bilgiler de basında yer almıştır. Her ne kadar orduda İttihat ve Terakki yanlıları kadar muhalifleri de olsa ve İttihat ve Terakki Hükümetinden rahatsızlık duysa da, esasen bir kaç münferit olay dışında ciddi bir hadise yaşanmamıştır ve İngiliz basınında yer alan bu tür haberler de dedikodu niteliğindedir. Ancak gene de bu tür haberlerin toplumlar ve ordular üzerindeki psikolojik etkilerini göz ardı etmemek gerekir.

\section{Baskının Uluslararası Siyasete Etkileri}

Mevcut uluslararası siyasetin de İngiliz basını tarafından dikkatle takip edildiği görülmektedir. Öncelikle İstanbul'daki hükümet değişikliği ve çatışmaların yeniden başlamasının, uluslararası bir karışıklık yaratabileceği ve Büyük Güçlerin arasındaki birliğin bozulabileceği, hatta Türkiye'nin de bunu umduğu; Romanya'nın Bulgaristan'dan toprak talepleri olduğu ve bu durumun Türkiye'yi cesaretlendirdiği; Büyük Güçlerin Çanakkale boğazına donanmalarını göndermesiyle Türkiye'nin şartları kabul edebileceği ve barışın sağlanabileceği, ancak Almanya ile AvusturyaMacaristan'ın bu kadar ileri gitmeye istekli olmadıkları; Rusya'nın Türkiye'ye Anadolu üzerinde askeri baskıda bulunup Balkan Koalisyonunu Balkanlar'da rahatlatabileceği, ancak bunun da Almanya ve AvusturyaMacaristan'ın tepkisini çekebileceği ve tehlikeli sonuçlara yol açabileceği; özellikle stratejik önemi çok yüksek olan İstanbul'un el değiştirme olasılığının Büyük Güçler arasında çok ciddi bir anlaşmazlık, hatta çatışma yaratabileceği yorumları bazı gazetelerde yer almıştır (The Falkirk Herald, 1913, 25 Ocak; Sunderland Daily Echo, 1913, 25 Ocak; The Courier, 1913, 25 Ocak; The Manchester Courier, 1913, 25 Ocak; The Western Times, 1913, 25 Ocak; Western Daily Press, 1913, 25 Ocak; Yorkshire Telegraph and Star, 1913, 27 Ocak).

İlerleyen günlerde İngiliz basını, Büyük Güçlerin tavırlarını ve arasındaki ilişkileri yakından takip etmeye devam etmiştir. Ancak Büyük Güçler 
arasında Türkiye'ye verilen Nota konusunda görüş ayrılığı olmadığ1 anlaşılmaktadır (The Aberdeen Daily Journal, 1913, 27 Ocak; The Derby Daily Telegraph, 1913, 27 Ocak; The Yorkshire Post, 1913, 25 Ocak; Tounton Courier, 1913, 29 Ocak; Yorkshire Telegraph and Star, 1913, 25 Ocak). Dahası, özellikle İngiltere, Fransa ve İtalya'nın Osmanlı Devleti üzerindeki baskılarını artırmak amacıyla savaş gemilerini Türk karasularına göndermeleriyle ilgili haberler basında yer almıştır. Bu haberlerde, İtalyan savaş gemileri San Mareo ile Pisa'nın Türk sularına intikal emri aldığ1; Yarmouth Kruvazörünün Suda Körfezine hareket emri aldığı; (The Aberdeen Daily Journal, 1913, 25 Ocak; The Devon and Exeter Gazette, 1913, 25 Ocak; The Manchester Courier, 1913, 25 Ocak; The Yorkshire Post, 1913, 25 Ocak) Malta Körfezindeki King Edward VII ve Zealandia adlı iki İngiliz savaş gemisinin Amiral Cecil Burney komutasında Türk karasularına intikal emri aldıkları; (The Evening News, 1913, 25 Ocak; Yorkshire Telegraph and Star, 1913, 27 Ocak) İngiltere'nin Inflexible adlı savaş kruvazörünün, üç eski zırhlı kruvazör, dört küçük kruvazör ve on destroyerden oluşan Akdeniz Filosunun Malta'da yola çıkmaya hazırlandığ1; Dördüncü Savaş Filosuna ait King Edward modeli altı savaş gemisinin Akdeniz'e ulaştığ1; (The Courier, 1913, 27 Ocak) Fransiz Dışişleri Bakanı M. Jonnart'ın Denizcilik Bakanlığından iki savaş gemisinin gerekli görülürse Yakın Doğu'ya gönderilmek üzere hazır edilmesini istediği; Ernest Renan ile Edgar Quinet'in halihazırda gönderilmeye hazır olduklarl; ayrıca dört adet Fransız savaş gemisinin ise Türk karasularında bulunduğu; İtalyan kruvazörleri Regina Elena, Emanuele ve Roma'ya hareket etme emri verildiği (Yorkshire Telegraph and Star, 1913, 27 Ocak) gibi bilgiler yer almıştır.

Bu bilgilerden İngiltere, Fransa ve İtalya'nın açıcça Osmanlı Devletinin karşısında ve Balkan Koalisyonunun yanında yer aldıkları anlaşılmaktadır. Almanya ve Avusturya ise Büyük Güçlerin ortak Nota'sına iştirak etmekle beraber, Osmanlı Devletine baskı yapacak kadar ileri gitmemeyi tercih etmişlerdir. Rusya'nın politikası da Osmanlı Devleti karşıtı ve Balkan Koalisyonu yanlısı olmasına rağmen Türk karasularına savaş gemisi göndermeyişinden, Almanya ve Avusturya'yı tahrik etmemek ve bu hassas durumda Büyük Güçlerin arasındaki fikir birliğini bozmamak için hassas ve mesafeli davrandığı anlaşılmaktadır. 
İngiltere, Fransa ve İtalya'nın açık desteğinden emin olan ve hükümetlerinden gereken talimatları almış bulunan Balkan Koalisyonu delegeleri, 26 Ocak akşamı saat 17:00 ila 18:00 arasında, Hyde Park Hotel'deki Sırp delegelerin merkezinde toplanmış ve Türk tarafına iletilmek üzere, görüşmelerin kesildiğine dair belgenin hazırlanmasına karar vermiştir. Her ülkeden bir delege görevlendirilerek Nota'nın metninin hazırlanması için bir kurul oluşturulmuştur (The Courier, 1913, 27 Ocak; The Derby Daily Telegraph, 1913, 27 Ocak; Yorkshire Telegraph and Star, 1913, 27 Ocak). İttihat ve Terakki Hükümeti ise Hariciye Nazırlığı için henüz uygun bir aday belirleyemediği gerekçesiyle Nota'ya yanıtı ertelemiştir (The Courier, 1913, 27 Ocak).

İttihat ve Terakki Hükümetinin Nota'ya yanıt vermeyi geciktirmesinin esas nedeni, Büyük Güçlerden Almanya ve Avusturya-Macaristan'ın desteğini sağlamak için zaman zaman kazanmak istemesidir. Çünkü bu sırada Beyazıt-Şişli arasında metro projesi için hükümet ile Alman Deutsche Bank arasında, bir Alman şirketine verilecek imtiyazın görüşmeleri yapılıyordu. Bu imtiyaz karşığında İttihat ve Terakki Hükümeti, bu ülkelerin diplomatik desteklerinin sağlanabileceğini, ayrıca olası bir savaşı finanse edebilmek için gerekli kredinin temin edilebileceğini ummaktaydı. Nitekim 28 Ocak tarihli gazetelerde, anlaşmanın imzalandığı ve projenin Deutsche Bank tarafından finanse edileceği haberleri yer almıştır. Ancak Deutsche Bank yetkilileri, projenin finansmanı haricinde, Osmanlı Devletine başkaca bir kredinin verilmediğini belirtmişlerdir (The Courier, 1913, 28 Ocak; The Scotsman, 1913, 28 Ocak; The Yorkshire Post, 1913, 28 Ocak).

Diplomasi alanında ise Alman Büyükelçisi Baron von Wangenheim'ın yaptığı açıklama dikkat çekicidir: "Ne şimdi ne de gelecekte hiç kimse Almanya'nın hayati çıkarlarının olduğu Küçük Asya'ya el süremeyecektir. Türkiye'nin geleceği Almanya'nın hayati çıkarlarının Türkiye'nin çıkarlarıyla sıkıca bağlı olduğu Küçük Asya'dadır. Barıştan sonra Almanya, Türkiye'nin kalkınması için güçlü destek verecektir." (The Daily Express, 1913, 30 Ocak; The Derby Daily Telegraph, 1913, 29 Ocak). Bu açıklamada "Küçük Asya" kavramı özellikle vurgulanmakta ancak Balkanlarla ilgili bir yorum yer almamaktadır. Von Wangenheim'ın açıklamasından öncelikle, Almanya'nın Balkan ihtilafı konusunda Osmanlı Devletine destek vermeyeceği, ancak Rusya'nın da ihtilafa müdahil olmasının Almanya 
tarafından hoş karşılanmayacağı anlaşılmaktadır. Ayrıca, Anadolu'nun Almanya'nın ekonomik nüfuz alanı içinde yer alması gerektiğinin mesajı verilmektedir. Nitekim bazı gazetelerde Almanya'da Ege'deki adaların Yunanistan'a verilmesine karşı çıkılması gerektiği görüşünün hakim olduğu, çünkü Yunanistan'ın, arkasındaki üçlü antant ile bölge ticaretini ele geçireceği ve bu durumda Almanya'nın, bunu kabul etmesi karşılığında değecek bir ekonomik genişleme tavizi alması gerektiği yönünde bilgiler yer almaktadır (The Daily Express, 1913, 30 Ocak). Kuvvetle muhtemeldir ki, bu ekonomik genişleme taviziyle kastedilen bölge Anadolu coğrafyasıdır.

Almanya ve Avusturya-Macaristan'in muhalefet etmeyeceklerinden de emin olan Balkan Koalisyonunun Nota'yı hazırlamakla görevli delegeleri çalışmalarını tamamlayarak, hazırladıkları Nota'yı, 29 Ocak günü öğleden sonra Türk delegelere iletmişlerdir. Nota'nın bir kopyası da Konferansın onursal başkanı Sör Edward Grey'e sunulmuştur (Evening Telegraph and Post, 1913, 29 Ocak; The Derby Daily Telegraph, 1913, 29 Ocak). Aynı gün, İngiliz Dışişleri Bakanlığında Sör Edward Grey, Fransız, Rus, Alman, Avusturya-Macaristan, İtalyan Büyükelçileri bir toplantı yapmışlardır (The Derby Daily Telegraph, 1913, 29 Ocak). İngiliz basınında toplantıda görüşülen konularla ilgili bir haber yer almasa da, Almanya ve Avusturya-Macaristan'ın ortak Nota'ya muhalefet ettiğine dair bir işaret de yoktur. Dolayısıyla İttihat ve Terakki Hükümetinin diplomatik çabalarından, Rusya'nın müdahale etme olasılığının bertaraf edilmesi dışında bir netice çıkmamıştır.

Diplomatik alanda umduğu desteği ve olası bir savaşta ordunun masraflarının karşılanması için gereken krediyi bulamayan İttihat ve Terakki Hükümeti oldukça zor bir durumda kalmıştır. Çünkü bir yandan olası bir savaş için koşullar son derece elverişsizken, diğer yandan Büyük Güçlerin Nota'sının kabulü de mümkün değildi. Çünkü İttihat ve Terakki Partisinin Kamil Paşa Kabinesini devirmesinin gerekçesi Kamil Paşa Kabinesinin Nota'yı kabul edecek oluşuydu. Ayrıca bundan dolayı, Kamil Paşa Kabinesine oldukça ağır eleştiriler yöneltmişlerdi.

Bu şartlar altında İttihat ve Terakki Hükümeti, bir orta yol izlemeye karar vermiştir. Büyük Güçlerin Nota'sına yanıt oldukça ılımlı bir üslupla hazırlanmış ve Edirne'de bir tarafsız statü oluşturulması, tahkimatların yıkılması, kutsal mabetlerin bulunduğu bölgelerin Osmanlı yönetiminde 
kalıp, Meriç'in sağ kısmında kalan bölgenin Bulgaristan'a devri; Ege'deki adalar konusunda da anakaraya yakın olanlarının Osmanlı egemenliğinde kalıp, adalar rejiminin Büyük Güçler tarafından belirlenmesinin kabul edileceği ifade edilmiştir (The Courier, 1913, 31 Ocak; The Evening News, 1913, 30 Ocak; The Manchester Courier, 1913, 31 Ocak; The Yorkshire Evening Post, 1913, 30 Ocak; The Yorkshire Post, 1913, 31 Ocak; Yorkshire Telegraph and Star, 1913, 30 Ocak). Yanıtta ilginç olan bir nokta da, Büyük Güçlerin Nota'da belirttikleri barıştan sonra Osmanlı Devletine yönelik ekonomik destek vaatlerine atıf yapılarak, Kapütilasyonların kaldırılmasının gerekliliğine vurgu yapılmış olmasıdır (The Yorkshire Post, 1913, 31 Ocak).

İttihat ve Terakki'nin bu yanıtından tatmin olmayan Balkan Koalisyonu delegeleri, barış görüşmelerini yeniden başlatmamış ve düşmanlıkların yeniden su yüzüne çıkma süreci başlamıştır. İttihat ve Terakki Hükümetinin yanıtı hakkında Reuter muhabirine demeç veren Bulgar misyonu başkanı Dr. Daneff: "Tüm müttefik misyonları adına şunu söyleyebilirim ki Türkiye'nin yanıtı yeni bir görüşme başlatmaya temel teşkil edecek bir yanıt değildir. Biz şunu belirttik ki Edirne ve Ege Adaları teslim edilecek ve bu olmadan görüşmelerin yeniden başlaması mümkün değil. Ayrıca bu devir çatışmalar başlamadan yapılmalıdır. İlk ateş durumumuzu değiştirir. Empatik olarak bu yanıt kabul edilebilir değildir" ifadelerini kullanmıştır. Ayrıca Dr. Daneff'in bu açılamayı, İngiliz Dışişleri Bakanlığına uğrayarak, Sör Edward Grey ile görüştükten sonra yaptığ 1 belirtilmektedir (The Yorkshire Evening Post, 1913, 30 Ocak; Yorkshire Telegraph and Star, 1913, 30 Ocak).

\section{Sonuç}

1. Balkan Savaşında Osmanlı Devleti ağır bir yenilgi almış, Büyük Güçler Edirne'nin ve Ege'deki adaların teslim edilmesi yönünde Osmanlı Devletine Nota vermiştir. İktidardaki Kamil Paşa Hükümetinin bu ağır şartları kabul etmek üzere olduğu bir aşamada, Edirne ve Ege'deki adaları elde tutmak amaciyla İttihat ve Terakki Partisi, 23 Ocak 1913 tarihinde, tarihe Bab-1 Ali Baskını olarak geçen bir darbeyle, Kamil Paşa Hükümetini devirerek İktidara gelmiştir. Ancak Osmanlı Devletinin içinde bulunduğu mevcut iç ve dış koşullar oldukça elverişsizdir. Öncelikle mali durum 
savaşın sürdürülmesine elvermediği gibi, kredi alınabilmesi de mümkün olmamıştır. Devrik Kamil Paşa Hükümeti yanlılarının muhalefeti de İttihat ve Terakki Hükümeti için istikrarsızlaştırıcı bir faktördür ve baskın sırasında Nazım Paşa'nın öldürülmesi de iç politikadaki ayrışmayı körüklemiştir.

Nazım Paşa'nın öldürülmesi, aynı zamanda uluslararası kamuoyunda İttihat ve Terakki Hükümetine yönelik antipatiyi de yükseltirken, Şerif Paşa gibi muhalif liderlerin açıklamaları, Osmanlı Devletinin mevcut zafiyetlerini de gözler önüne sermiştir.

İttihat ve Terakki Hükümeti Almanya'ya imtiyaz vererek, Almanya ve Avusturya-Macaristan'ın desteğini sağlamaya çalışmışsa da, bu destek sadece Anadolu'daki toprak bütünlügüne yönelik kalmış, Balkanları kapsamamış ve ancak Rusya'nın uzak tutulabilmesini sağlamıştır. Buna karşı, İngiltere, Fransa ve İtalya Osmanlı karasularına savaş gemileri göndermek suretiyle kararlılıklarını ortaya koyarak bir yandan Osmanlı Devleti üzerindeki baskılarını artırmış, diğer yandan da Balkan koalisyonuna yönelik desteklerini aktif olarak, açıç̧a ortaya koymuşlardır.

Mevcut iç ve dış koşulların bu denli olumsuzluğu karşısında, İttihat ve Terakki Hükümeti Büyük Güçlerin Nota'sına 1lımlı bir üslupla bir “orta yol" önerisiyle yanıt vermiştir. Ancak şartların Osmanlı Devleti açısından olumsuzluğu, Balkan Koalisyonu açısından değerlendirildiğinde elbette ki, gayet olumlu olduğu anlamına gelmektedir ve Balkan Koalisyonu Hükümetleri, bu şartlar altında, İttihat ve Terakki Hükümetinin önerisini reddetmişlerdir. Sonuç olarak İttihat ve Terakki Hükümetinin, Ege'deki adaların ve Edirne'nin elde tutulması amacını gerçekleştirebilmesi mümkün olmamıştır. 


\title{
EXTENDED ABSTRACT
}

\section{The Raid of The Porte and Its International Repercussions According to The British Press}

\author{
Özgür Çınarl1 - İsmail Safi \\ Aksaray University - Istinye University
}

In 23th January 1913, Union and Progress Party organized a coup against the leading Kamil Pasha Cabinet and aquired power. This coup is named as "the raid of the Porte". The main reason of the coup was Kamil Pasha Cabinet's acceptance of the memorandum of the Great Prowers, which was given after the defeat of the Ottoman forces in the first Balkan War and included the surrender of one of the oldest capitals of Edirne and the Islands in the Eagean sea. The aim of the Union and Progress Party was the protection of these reagions, by monopolizing every possibility at hand. The raid of the Porte, an important breakpoint in Turkish politics, is an important area under the leadership of Enver Paşa. In the history of democracy in Turkey, one of the first coups can be seen as a consequence of the monopolization of political power by the Union Committee and Progress. However, they could not be successful in reaching this aim.

The Ottoman Empire suffered a heavy defeat during the Balkan War. The great powers gave a memorandum to the Ottoman State for the delivery of Edirne and islands of the Aegean Sea. While the government of Kamil Pasha's government was about to accept these cumbersome conditions, the Committee of Union and Progress met on January 23, 1913 to preserve Edirne and the Aegean Islands with the raid of the Porte. However, the existing internal and external conditions in which the Ottoman Empire located are unfavorable. First of all, the financial situation did not allow the continuation of the war and it was not possible to obtain credit. The opposition of Kamil Pasha's government supporters had also been a destabilizing factor for the Union and Progress movement, and the assassination of Nazim Pasha during the raid of the Porte had fueled the divergence of domestic politics. 
The assassination of Nazim Pasha also provoked antipathy towards the Committee of the Union and Progress in international public opinion, while declarations by opposing leaders such as Şerif Pasha revealed the existing weaknesses of the Ottoman state. The Gouvernment of Union and Progress granted a concession to Germany. The gouvernment tried to take support Germany and Austria-Hungary. But this support only remained for the territorial integrity in Anatolia, does not include the Balkans, but the support of Germant to the Ottoman Empire allows to leave Russia. On the other hand, Great Britain, France and Italy increased their pressure on the Ottoman state by showing their determination by sending battleships into Ottoman territorial waters.

The question was whether the new government in Istanbul could be permanent or not. Although the coup of the Committee of Union and Progress had been successful, the former government was known to have supporters especially within the army. In such a situation, Edirne and Aegean islands were expected to be removed from the Ottoman State without further conflict. But even if there were no counter-revolution, the instability created by the opposition within the country could force the Union and Progress Government to pay attention to its internal affairs and soften it insist on keeping Edirne. Faced with the negativity of existing internal and external conditions, the Union and Progress Gouvernment responded to the Great Powers Memorandum by a modest means of suggesting a middle way. However, the negativity of the conditions relating to the Ottoman Empire, of course, when it considered from the angle of the Balkan coalition, means that it was very positive. In these circumstances, the governments of the Balkan Coalition rejected the proposal of the Union Government and Progress.

As a result, the Union and Progress Government was unable to achieve the goal of Edirne's detention and the aegean islands. Following the Balkan Wars, the Ottoman Empire lost almost all of its territory in the Balkan region. The victories of the states that left the Ottoman Empire against the Ottoman Empire made the Union and Progress more and more authoritarian and after 1913, that is, after the defeat of the Balkan Wars, the Unionist dictatorship began in the Ottoman Empire. For this reason, the raid of the Porte constituted a break point for Turkish political history and for the Committee on Union and Progress. Army pressure on politics grew 
after the raid of the Porte. The relations between army and politics integred. In addition, during the raid of the Porte, the assassination of Nazim Pasha had become a growing assassination's policy and had even become a policy of the Commitee of the Union and Progress. This work observes the process and the repercussions of the coup by using the British printed media, and puts forward the failure of its aim, with its internal and external reasons.

\section{Kaynakça / References}

Dundee Evening Telegraph and Post. (1913, 3 Şubat).

Gloucaster Journal. (1913, 25 Ocak).

Sunderland Daily Echo. (1913, 24 Ocak).

Sunderland Daily Echo. (1913, 25 Ocak).

The Aberdeen Daily Journal. (1913, 6 Ocak).

The Aberdeen Daily Journal. (1913, 25 Ocak).

The Aberdeen Daily Journal. (1913, 27 Ocak).

The Courier. (1913, 13 Ocak).

The Courier. (1913, 25 Ocak).

The Courier. (1913, 27 Ocak).

The Courier. (1913, 28 Ocak).

The Courier. (1913, 31 Ocak).

The Daily Express. (1913, 25 Ocak).

The Daily Express. (1913, 30 Ocak).

The Derby Daily Telegraph. (1913, 24 Ocak).

The Derby Daily Telegraph. (1913, 27 Ocak).

The Derby Daily Telegraph. (1913, 29 Ocak).

The Devon and Exeter Gazette. (1913, 25 Ocak).

The Devon and Exeter Gazette. (1913, 28 Ocak).

The Evening News. (1913, 23 Ocak).

The Evening News. (1913, 24 Ocak).

The Evening News. (1913, 25 Ocak).

The Evening News. (1913, 30 Ocak).

The Evening Telegraph and Post. (1913, 9 Ocak).

The Evening Telegraph and Post. (1913, 29 Ocak).

The Evening Telegraph and Post. (1913, 31 Ocak).

The Falkirk Herald. (1913, 25 Ocak). 
The Fife Free Press. (1913, 25 Ocak).

The Mancester Courier. (1913, 28 Ocak).

The Manchester Courier. (1913, 10 Ocak).

The Manchester Courier. (1913, 13 Ocak).

The Manchester Courier. (1913, 23 Ocak).

The Manchester Courier. (1913, 25 Ocak).

The Manchester Courier. (1913, 28 Ocak).

The Manchester Courier. (1913, 30 Ocak).

The Manchester Courier. (1913, 31 Ocak).

The Manchester Courier. (1913, 6 Ocak).

The Manchester Courier. (1913, 7 Ocak).

The Nottingham Evening Post. (1913, 24 Ocak).

The Scotsman. (1913, 28 Ocak).

The Western Times. (1913, 10 Ocak).

The Western Times. (1913, 25 Ocak).

The Yokshire Evening Post. (1913, 24 Ocak).

The Yorkshire Evening Post. (1913, 30 Ocak).

The Yorkshire Post. (1913, 25 Ocak).

The Yorkshire Post. (1913, 28 Ocak).

The Yorkshire Post. (1913, 31 Ocak).

Tounton Courier. (1913, 29 Ocak).

Western Daily Press. (1913, 25 Ocak).

Yorkshire Telegraph and Star. (1913, 23 Ocak).

Yorkshire Telegraph and Star. (1913, 24 Ocak).

Yorkshire Telegraph and Star. (1913, 25 Ocak).

Yorkshire Telegraph and Star. (1913, 27 Ocak).

Yorkshire Telegraph and Star. (1913, 30 Ocak).

\section{Kaynakça Bilgisi / Citation Information}

Çınarlı, Ö. ve Safi, İ. (2019). İngiliz yazılı basınına göre Bab-1 Ali baskını ve uluslararası sonuçları. OPUS-Uluslararası Toplum Araştırmaları Dergisi , 10(17), 1786-1808. DOI: 10.26466/opus.512811 